\title{
IMPACT OF SMALL SCALE MINING ON RURAL LIVELIHOODS IN SOME PARTS OF YAURI AND FAKAI LOCAL GOVERNMENT AREAS OF KEBBI STATE, NIGERIA
}

\author{
${ }^{* 1}$ Abubukar, M. Y, ${ }^{2}$ Zankan, J. A. A and ${ }^{3}$ Isah, M. N. \\ ${ }^{1,2}$ Department of Geography, Bayero University Kano, Nigeria, \\ ${ }^{3}$ Nasarawa Urban Development Board, Lafia, Nasarawa State, Nigeria \\ Corresponding Author's Email: myazidabubakar3@gmail.com Tel- +2348069257894 \\ DOI: $10.31364 / \mathrm{SCIRJ} / \mathrm{v} 8.14 .2020 . \mathrm{P} 0420769$ \\ http://dx.doi.org/10.31364/SCIRJ/v8.i4.2020.P0420769
}

\begin{abstract}
Small scale mining is an important livelihood activity to most rural dwellers living in communities endowed with mineral resources. This study examined the impact of small scale mining on rural livelihoods in some parts of Fakai and Yauri local government areas of Kebbi State, Nigeria. Data for this study was collected through direct field observation and focus group discussion (FGD). Six different sessions of FGD of eight participants was conducted which were purposely selected based on their participation and knowledge in mining. The results of the study indicated that the mining activities is undertaken by individuals and groups who rely heavily on manual labour, using simple implements such as chisel, hammer, digger and shovel. The constraints to mineral exploitation include rock falls and subsidence, drug abuse and addiction, use of crude equipments, exposure to dust/health risk, and security challenges. The findings also revealed the following as the benefits of small scale mining in the study area: source of income generation, it creates employment to people, improves crop farming and livestock production, and improves petty trading and blacksmithing. It is therefore recommended that miners should suspend mining activities during the rainy season in other to avoid subsidence or rock falls and revisit their farmlands for agriculture. They should be educated on the dangers of drug abuse and also advice to eat nutritious and palatable food to maintain healthy living. Finally, they should sponsor their children to study so as to reduce their suffering from mining.
\end{abstract}

\section{Keywords: Small Scale Mining, Livelihoods, Miners, Minerals, Options, Community}

\section{INTRODUCTION}

Mining is one of the oldest economic activities in Nigeria dating back to prehistoric times when man crudely exploited iron and clay, and perhaps other metals, for the production of his cosmetics, crude implements and utensils (Davou, 2013). The development of natural resources worldwide involves the manipulation of the environment to arrive at specific objectives. Mineral resource is the most exploited natural resource and involves extraction, grinding, ore concentration and dispersal of tailings (Girigisu, 2012). Small scale mining is believed to constitute over $95 \%$ of mining taking place in Nigeria (Lawal, 2002). Gold, columbite, tin, tantalum, gemstones (such as emerald, aquamarine, and tourmaline), barite, gypsum, limestone, kaolin, rock aggregate, and salt are the most important minerals mined at the small scale mining level in Nigeria (Michelou, 2006). Broadly speaking, it is difficult to make general conclusions about small scale mining because of varied of factors such as accessibility to minerals, the miners are committed to either

Www.scirj.org

(C) 2020, Scientific Research Journal

http://dx.doi.org/10.31364/SCIRJ/v8.i4.2020.P0420769

This publication is licensed under Creative Commons Attribution CC BY. 
a specific site or mineral and the practice is not standardized because of differences in technical knowledge and skills, cultural and geographic affiliations, types of minerals mined, social and environmental factors, level of formalization, and access to markets (MMSD, 2008).

The situation in Nigeria is that the government cannot cater for the basic needs of its teeming population. That calls for people to resort to any livelihood activities. For example, Zankan (2018) noted that there are many people in Nigeria who have acquired higher qualifications such as NCE and diploma that supposed to have been employed by the government or other private organizations but are left idle which have forced them to look for other livelihood options such as commercial woodfuel harvesting to support their families in buying, food, clothes and payment of their children school fees. Livelihood comprises the capabilities, assets (stores, resources, claims and access) and activities required for a means of living (Chambers et al, 1991). It is sustainable when it cope with and recover from stress and shocks, maintain or enhance its capabilities and assets, and provide sustainable livelihood opportunities for the next generation, and which contributes net benefits to other livelihoods at the local and global levels and in the short and long term.

Many studies have been conducted in Kebbi State about small scale mining. Most of the studies were mainly on the dangers of small scale mining on the environment; examples of such studies include Girigisu (2012) and Salati (2014), characterization of gold mineralization, Talaat et al, (2010) and Identification of mineral deposits in the mining sites, Sani et al. (2019). Unfortunately, no study has been documented about the impact of small scale mining on rural livelihood in Fakai and Yauri local government areas especially that the majority of people are living in rural areas in Kebbi State. Therefore, this paper examined the impact of small scale mining on rural livelihood in some parts of Fakai and Yauri local government areas of Kebbi State, Nigeria with a view to provide information for sustainable management of the natural resources.

\section{MATERIAL AND METHODS}

\section{The Study Area}

Yauri and Fakai Local Governments Areas are located between latitudes $10^{\circ} 10^{\prime} \mathrm{N}$ and $11^{\circ} 40^{\prime} \mathrm{N}$ of the equator and longitude $3^{\circ} 30^{\prime} \mathrm{E}$ and $5^{\circ} 10^{\prime} \mathrm{E}$ of the Greenwich meridian. The local governments shares local boundaries with Ngaski Local Government to the West, Zuru and Danko local Governments to the east, Kebbe Local Government Area of Sokoto State to the North, and Rijau Local Government of Niger State to the South. Yauri and Fakai have a total land area of about 3,380km ${ }^{2}$ and $^{2,247 \mathrm{~km}^{2}}$ respectively $\left(\mathrm{KBSG}_{\text {, }}\right.$ 2008) (Figure1).

WwW.scirj.org

(C) 2020, Scientific Research Journal

http://dx.doi.org/10.31364/SCIRJ/v8.i4.2020.P0420769

This publication is licensed under Creative Commons Attribution CC BY. 
The study area falls within a vast, geologically well noted zone called Birnin Yauri in the north-west of Nigeria. Primary gold mineralization in the schist belt commonly occurs in quartz veins within several lithology. Both Tondi Gada and Garin Hawal falls to the Birnin Yauri deposit of schist belts of northwestern Nigeria. They are both of vein-type quartz-sulphide carbonate gold mineralization hosted by a brittle fault zone. The areas are characterized with flat topography with a few elevated areas. It is an extension of the Sokoto plain: dotted with some doom-shaped hills and complemented by a portion of the great river Niger and its numerous tributaries, which gently meanders on the landscape (Udu, 1991). 


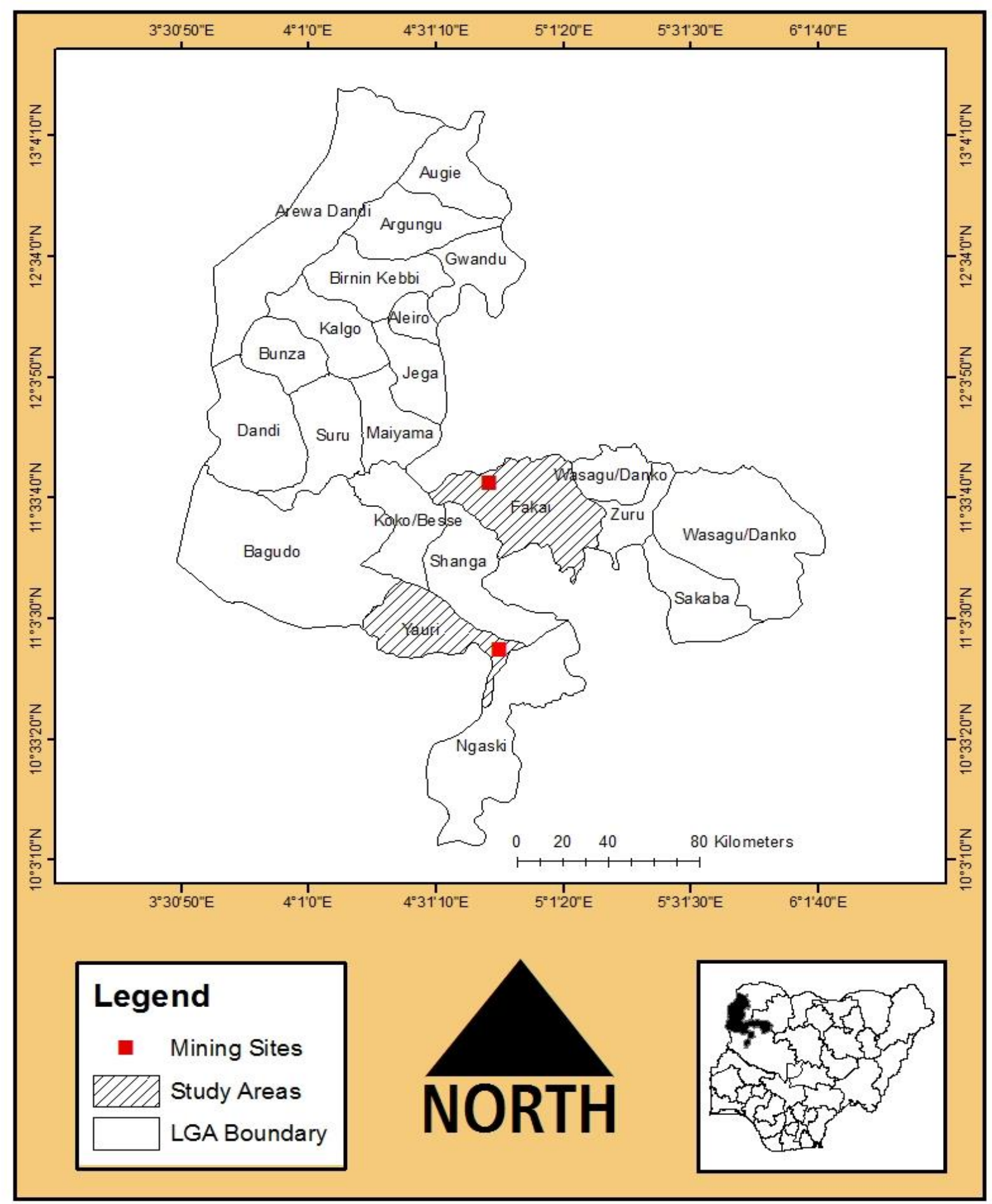

SOURCE: GIS \& CARTOGRAPHY UNIT GEOGRAPHY DEPT. BUK (2019)

Figure 1: Kebbi state showing the study area. 


\section{DATA COLLECTION}

The data for this study was collected through Focus group discussion and direct field observation. Checklist that contains questions based on the objectives of the study was used to collect data. FGD was conducted to acquire information on the impact of small scale mining and livelihoods in the study area. The sample for the focus group discussion was purposively selected based on their knowledge and participation in mining and livelihoods activities. The study had six focus groups sessions of eight participants from the study area, totaling forty eight participants. The participants for the FGD include small scale miners, food vendors, blacksmiths, petty traders and transporters. It was conducted at the mining sites. Participants' views were recorded and transcribed. Field observations also help the researcher in identifying the processes of mining in the study area. The FGD had a moderator who facilitated the discussion and a note taker who took notes of responses from the participants and also ran the tape recorder that was provided for the survey.

\section{TECHNIQUES OF DATA ANALYSIS}

The results obtained from FGD and field observation were transcribed and explained in narrative format. Transcription was used to analyze the data from FGD. Transcription is a process of turning written record or speech into forms where the meaning can be extracted for analytical interpretation. The field notes and audio records and field observation that cover events and activities observed were used for the analysis. Summary of some information were represented in tables, figures and plates.

\section{RESULTS AND DISCUSSION}

\section{PROCESSES INVOLVED IN MINERAL EXPLOITATION IN TONDI GADA AND GARIN HAWAL}

The processes of mineral exploitation in the study area was observed to be subdivided into three ways depending on the position of the mineral deposit: underground mining which is a type of mining that is more expensive and are often used to reach deeper deposits, open pit mining which is typically used for more shallow minerals and placer mining (alluvial or colluvium) which is the method used to sift out gold from sediments in river channels.

www.scirj.org

(C) 2020, Scientific Research Journal

http://dx.doi.org/10.31364/SCIRJ/v8.i4.2020.P0420769

This publication is licensed under Creative Commons Attribution CC BY. 


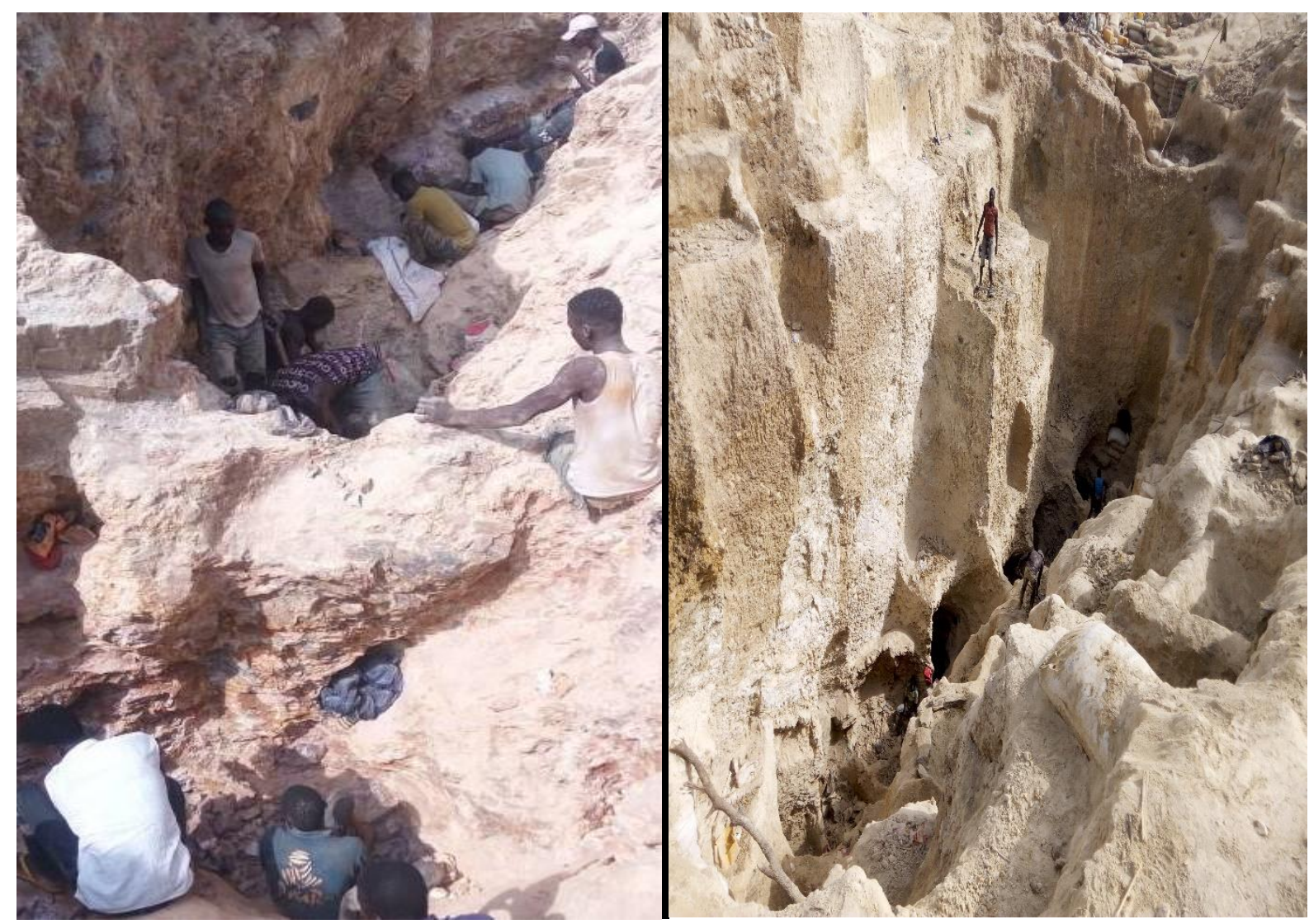

Source: Fieldwork, November, 2017.

Source: Fieldwork, November, 2017.

Plate 1 Open pit mining

plate 2 Underground mining

\section{Instruments for the Extraction of Gold in Tondi Gada and Garin Hawal}

The instruments used for the extraction of gold in Tondi Gada and Garin Hawal include crude implements such as crowbars, axes, hammers, buckets, shovels, chisel, digger, and crusher jaw. Plate 1 and 2 illustrate how miners are excavating gold-bearing rocks with some basic equipment such as crowbars, axes, hammers, buckets, shovels, chisel and digger. It was observed that gold is the major mineral mined in the two communities. Gold-containing rocks are crushed which reduces the physical size of large rocks, exposing more surface area of rock, thus exposing any gold that embedded in the rock and increasing the probability of obtaining the gold from the rock by gravity concentration or by leaching with cyanide.

Rocks are broken by the addition of energy in the form of an impact hammer, crusher jaw, and grinding machine which results in smaller particles and leach it with cyanide to obtained gold.

WwW.scirj.org

(C) 2020, Scientific Research Journal 


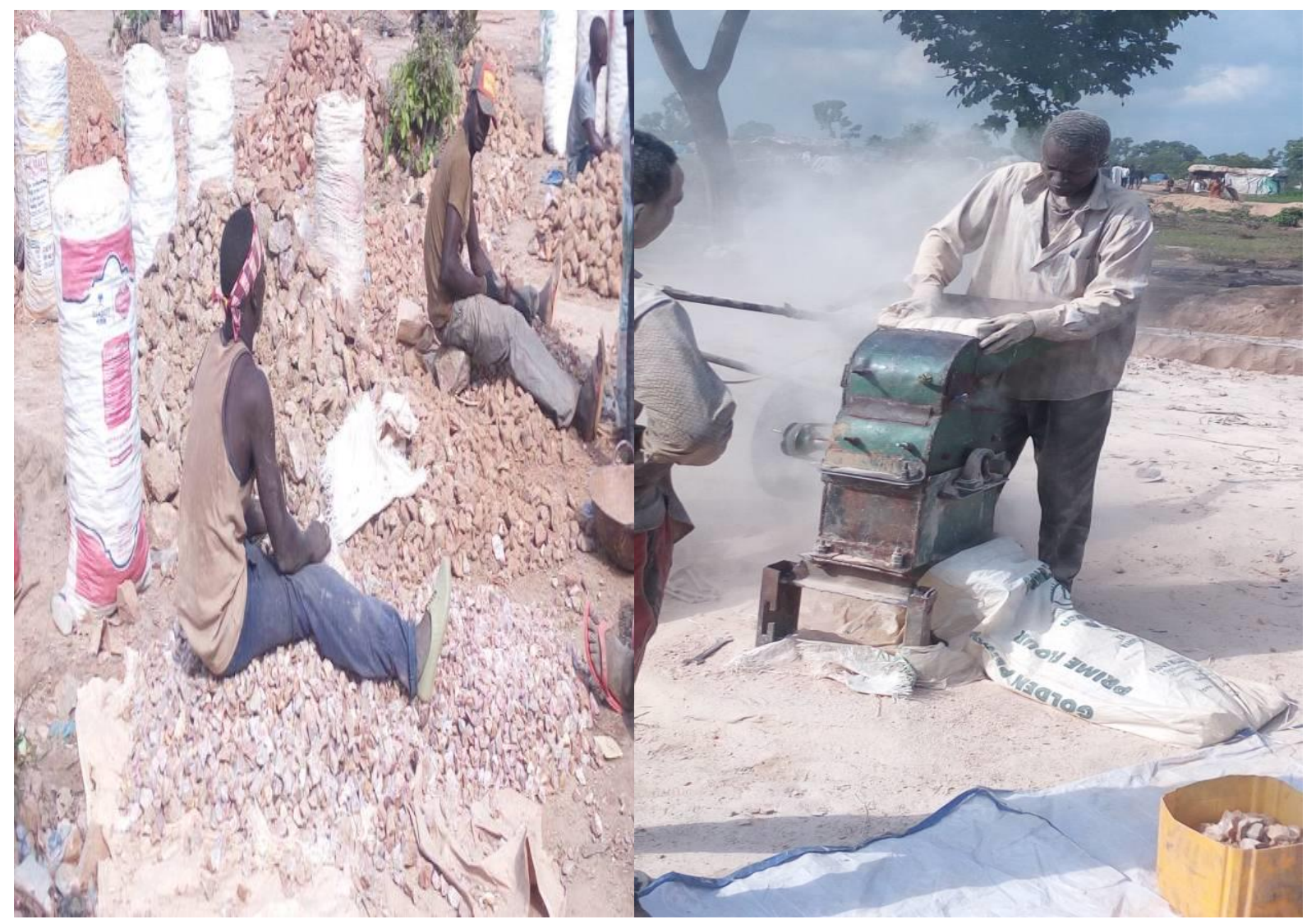

Source: Fieldwork, November, 2017.

Plate 3 crushing of rocks into coarse particles
Source: Fieldwork, November, 2017.

Plate 4 grinding of rocks into fine particles

Common rock types in the study community have a wide range of crushability (i.e. the ease with which a rock is crushed). The table 1 shows a number of rock types and their relative crushability. As one can see, rocks with high amounts of quartz are harder than those with no or little quartz and thus require considerable effort to crush.

Table 1: Types of Rocks and their Relative Crushability

\begin{tabular}{|c|c|}
\hline Type of Rock Hardness & Hardness \\
\hline Basalt & Very hard \\
\hline Granite & \\
\hline Quartz/quartzite & \\
\hline Copper ore & \\
\hline Iron ore & \\
\hline Sandstone & \\
\hline
\end{tabular}




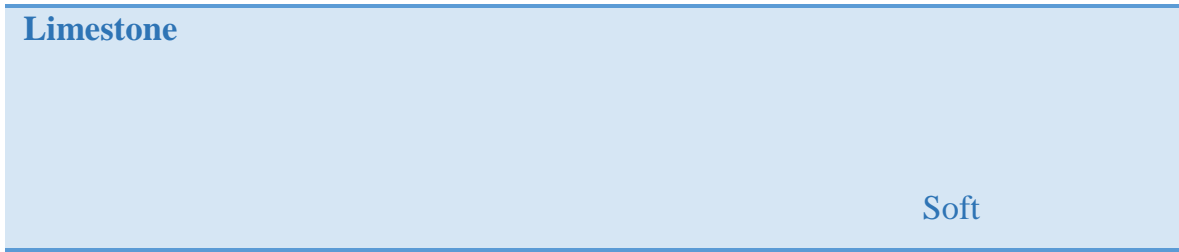

Source: Fieldwork, November, 2017

After undergoing stages of crushing and grinding, miners take the fine particles for sluices. Sluices are inclined, flat-bottomed troughs that are lined on the bottom with a trapping mechanism that can capture particles of gold and other heavy minerals. They can be used either for alluvial or for primary ore (sluices are sometimes called "strakes" or "blanket tables"). Ore is mixed with water and the pulp poured down the trough. Thereafter the lining particles are put in one place and leach it with cyanide, which attracts gold and other metals.

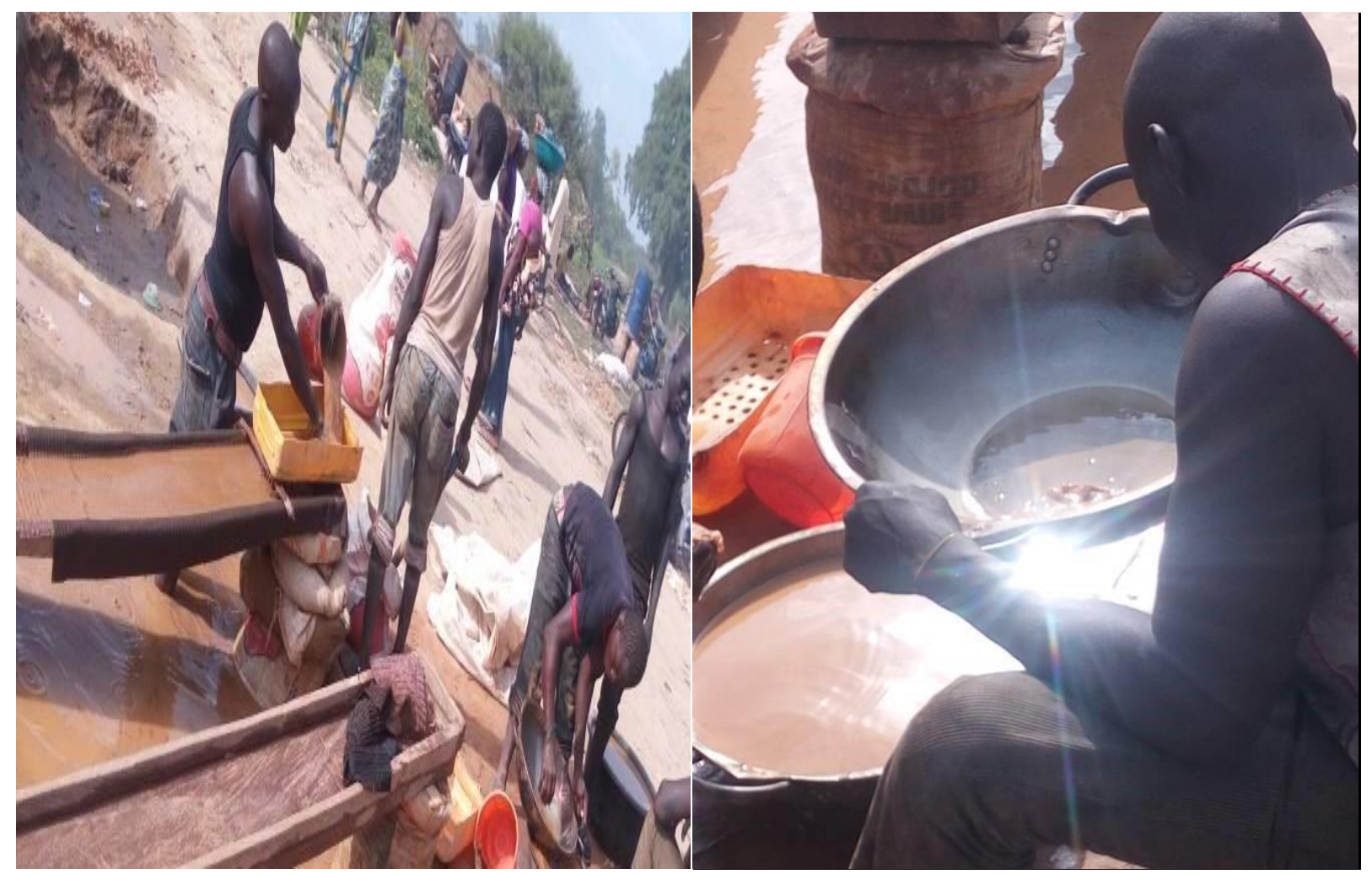

Source: Fieldwork, December, 2017.

Source: Fieldwork, December, 2017.

Plate 5 Sluicing

Plate 6 adding cyanide to obtain gold

It was gathered that gold dealers use "carat" to describe the purity of gold in the study area and is based on a total of 24 parts. Pure gold is known as 24 carat. In 18 carat gold, for example, 18 of the 24 parts are gold and the remaining 6 parts are another metal, such as silver or copper. However study participants lamented that gold dealers usually do not pay them the same gold value.

\section{THE CONSTRAINTS MINERS FACE DURING MINERAL EXPLOITATION}

WwW.scirj.org

(C) 2020, Scientific Research Journal 
Most of the participants outline the following as the factors affecting them in the mining process: the used of crude implement, Security challenges, high level of exploitation, rock falls and subsidence and exposure to dust among others.

The used of crude implement: Most of the participants lamented on rudimentary condition of the equipment used in the extraction processes which is also a problem hindering excavation and make it difficult to disintegrate rocks thereby confounding the daunting nature of the work.

Security challenges: most of the FGD participants also noted that they find it difficult to have access to explosive devices which makes their works very easy due to Boko Haram insurgences that engulfed the northern part of the country. Initially dynamite was used to explode rocks into pieces but this doesn't happen today because of the poor security situation in the country. Apart from lack of access to explosive devices, armed robbers have attacked the miners in several occasions which have discouraged many of them from participating in the mining work. The security agencies such as police and Civil Defence Corps do not have time for the miners which give armed robbers the opportunity to operate at will without any challenge.

High level of exploitation by their intermediaries: The focus group participants also claimed that they are being exploited by intermediaries (sponsors). These sponsors mostly underpay the small scale miners for the minerals being supplied. The intermediaries do give them money and also provide food for them with the hope that when they get the minerals, they would sell it directly to them. This sometimes affect the miners because they do not have right to sell it to another person no matter the amount of the mineral value.

Exposure to Dust/Health Risk: The FGD participants noted that among the most prevalent negative issues associated with small scale mining activities include exposure to dust which causes serious respiratory diseases such as asthma. This has forced many people to withdraw from involving in the small scale mining. This supported the study of Aigbedion et al. (2007), which confirmed that large volume of dust from mining operations in Nigeria is being discharged daily into the air that affect human health.

Rock falls and subsidence: Some of the participants confirmed that rock falls and subsidence also affect them as it has led to loss of lives in the mining areas especially during the rainy season when soil is saturated with water. For example, subsidence claimed the lives of eight (8) miners in 2015 at Tondi Gada and Garin Hawal. This study is in conformity with Adekoya (2003) which reported that mining operations normally upset the equilibrium in the geological environment, which may trigger off certain geological hazards such as landslide, subsidence, flooding, erosion and tremors together with their secondary effects.

It was observed and attested by the miners that they take drugs such as paracetamol, tramadol, marijuana, alcohol and other stimulants. which they claimed that they used these drugs as a result of strenuous nature of small scale mining activities, especially

$$
\text { WwW.scirj.org }
$$

(C) 2020, Scientific Research Journal

http://dx.doi.org/10.31364/SCIRJ/v8.i4.2020.P0420769

This publication is licensed under Creative Commons Attribution CC BY. 
when they entail digging to reach deep mineral veins to cope with the daunting nature of the work. One participant from Tondi Gada confirmed that:

I used to take some of these drugs as a form of stimulant to raise my level of physical activity and sometime to treat body pains (Tanko, pers., com., December, 2017).

There are also the effects of noise and vibration, inadequate ventilation and misuse of explosives also confounded the issue of mineral exploitation.

\section{THE BENEFITS FROM SMALL SCALE MINING}

Small scale mining has broad impact on social and economic well-being of the individuals and communities where it is practiced which virtually affects their livelihoods sustainability. Some of the benefits generated form small scale mining includes the following:

Small Scale Mining as Source of Income Generation in Tondi Gada and Garin Hawal: Most of the focus group participants identified income generation through the mining as one of the driving force for their involvement in small scale mining in Garin Hawal and Tondi Gada. They noted that mining have yielded much needed capital to develop and support other positive economic and social activities, in which farming, trading and health care are being diversified and expanded. Mining offers possibilities to improve their well-being and productivity. It was attested by the FGD participants that they generate income and most of them claimed that they gained at least 5,000 per team on daily basis, which no any other livelihood pays higher than this. When asked about the benefits they generates from mining. One participant from Tondi Gada has this to say:

I can only thank God for this business because money I generated from this work has enable me to buy a generator, cows and build a house for myself and family. Initially I was living in our nucleated family house in single room with my family but today I have my personal house (Isah, pers. Com., December, 2017).

Apart from building of houses with the money obtained from small scale mining, some of them got married and others had additional wives with the money they have generated from mining. For example, a participant from Garin Hawal, buttressed that:

To be candid with you, no job pays more than this mining in this our community, so I am here every day, this is my only job, As you can also see for yourself it provides labour qualification for all in as much you have energy to work and perseverance, it doesn't required any paper qualification or you need to know somebody before you work here (Jatau, pers. Com., November, 2017).

The incentive to raise capital for other alternative livelihoods is also the benefits that the small scale miners are generating from mining. The result of this study confirmed the result of Mondlane and Shoko (2003), in their study of the Niassa and Manica communities in Mozambique which noted that $30 \%$ of rural inhabitants engaged in small scale mining to augment agriculture from the mining earnings. Many miners have also admitted that the high financial incentive that small scale mining offers when compared www.scirj.org

(C) 2020, Scientific Research Journal

http://dx.doi.org/10.31364/SCIRJ/v8.i4.2020.P0420769

This publication is licensed under Creative Commons Attribution CC BY. 
to other livelihood activities like farming, carving, fuel wood selling, charcoal production, hunting, animal herding, fishing, driving and trading is what triggered them to be involved into mining.

Small Scale Mining as a Source of Employment Opportunity in Tondi Gada and Garin Hawal: Most of the participants noted that small scale mining have employed many of them as some of them are the exploiters, while other are buyers which opened a wide market for people in the study area. In addition to offering direct employment to the members of these communities, mining have also creates opportunities for other small businesses like petty trading, food vendors, fuel sellers, transporters, mineral dealers and hawkers. From the above information, it indicates that mining is the most rewarding activities, whereas other activities are largely subsistence. Is also confirmed that the quest to provide family and personal needs such as food and shelter was a key driver for community involvement in small scale mining.

Small Scale Mining Improves livestock and Crop Farming in Tondi Gada and Garin Hawal: Most of the FGD participants indicated that mining has boosted their livestock production and crop farming. This is because it enables them to buy more farming inputs such as hybrid seeds, fertilizer, herbicides and insecticides. It gives the opportunity to buy and more livestock such as goats, cows and sheep. They buttressed that with this modern agriculture one needs only to till his farm for seed preparation and subsequently spray herbicides for weed control. One of the miners at Garin Hawal claimed that:

I have even expanded the size of my farmland because of the huge amount of money I used to acquire from the small scale mining (Nuhu, pers. com., November, 2017).

It was observed that miners who still engaged in farming as another means of livelihoods have good markets for their farm produce because of the increased market size and high level of miners' incomes. This work is contrary to Oladeji et al. (2010) which found that mining activities involving the open cast method have adverse effect on people and agriculture as a result of excavation of mineral and materials during mining operation. This may be as a result of differences in cultural and geographic affiliation, environment or even the mineral being mined in the study area. Direct field observation shows that mining activities in Tondi Gada and Garin Hawal are mostly located at the uplands. However, some of the miners do go back to their farms during the rainy season to produce crops and go back to mining during the dry season to raise money in preparation for the rainy season.

Livestock rearing is also flourishing. They used the money acquired from mining to buy supplements and medical care for their livestock in order to improve production and health status of the animals. This agrees with Olayide (2011) which revealed that livestock rearing is another source of livelihood and is favoured by mining activities. Rearing livestock in the study area is done by both men and women to feed their family and sell to generate income.

$$
\text { WwW.scirj.org }
$$

(C) 2020, Scientific Research Journal

http://dx.doi.org/10.31364/SCIRJ/v8.i4.2020.P0420769

This publication is licensed under Creative Commons Attribution CC BY. 
Small Scale Mining improves Blacksmithing in Tondi Gada and Garin Hawal: Blacksmithing is also one of the livelihood activities that are influenced by small scale mining in the study communities. It was gathered that blacksmithing is as old as farming but was not active until the onset of small scale mining in the community. The small scale mining gives the blacksmiths the opportunity to earn income from the miners through forging of irons to provide mining equipments such as diggers and shovels mining. The metals are shaped by heating and hammering in order to suit the needs of miners. One of the participants from Tondi Gada buttressed that:

The blacksmithing was almost dormant in the mining community but the advent of mining has been revived the blacksmithing work and now we make money from it (Audu, pers., com. December, 2017).

Small Scale Mining Improves Petty Trading and Food Vending in Tondi Gada and Garin Hawal: Petty trading and food vending in the study area are influenced by small scale mining considering the number of people that involved in the mining that need food, clothes and other stuff. Most of those who engaged in petty trading are mostly women who do not have the strength to involve in digging of the ground in searching of the minerals. They used the opportunity to buy food which is sold to the miners at high prices to generate more money for themselves and their families. It was attested by one participant from Tondi Gada that:

Coming out of the mining sites to get edible things is always difficult and expensive. Some miners have no any other option than to buy food and snacks from us which help us to generate income (Kulu, pers., com. December, 2017).

The results of this study also conformed to the work of Hayes (2008) and Girigisu (2012), which stressed that mining operation generates a lot of survival related activities such as petty trading to accumulate a lot of wealth.

\section{CONCLUSION}

Despite the constraints in mineral exploitation, mining has influenced rural livelihoods and reduced high poverty rate in the mining communities. This is because of the benefits generated from mining which include job and wealth creation for community members which help them to improve farming tremendously and complements other livelihoods such as petty trading, food vending and blacksmithing. Miners earn relatively high incomes within a short time period compared to any other activity in mining communities. It is therefore recommended that miners should suspend mining activities during the rainy season in other to avoid subsidence or rock falls and revisit their farmlands for agriculture. They should be educated on the dangers of drug abuse and also advice to eat nutritious and palatable food to maintain healthy living. Finally, they should sponsor their children to study so as to reduce their suffering from mining.

www.scirj.org

(C) 2020, Scientific Research Journal

http://dx.doi.org/10.31364/SCIRJ/v8.i4.2020.P0420769

This publication is licensed under Creative Commons Attribution CC BY. 


\section{REFERENCES}

Adekoya JA (2003). Environmental Effect of Solid Minerals Mining. Kenya Journal of Physical Science, Vol.30 (2): 625-640.

Aigbedion, I and Iyayi, S. E (2007). Environmental effect of mineral exploitation in Nigeria. International Journal of Physical sciences, Vol.2 (2): 33-38.

Chambers, R., and Conway, G.R., (1991). Sustainable Rural Livelihoods: Practical Concepts for the 21st Century. Institute of Development Studies DP 296. University of Sussex: Brighton.

Danbatta, U. A. (2008). Precambrian Crustal Development in the Northwestern Part of Zuru Schist Belt, Northwestern Nigeria. Journal of Mining and Geology. 44 (1):45-56.

Davou, D. D. (2013, December). Introduction. In short course on environmental procedures, Nigerian institute of mining and geoscience, Jos, Nigeria.

Girigisu, S., (2012). Assessments of radiological levels and elemental concentrations in soils from Awwal and Bagega gold mining sites in Kebbi and Zamfara states, Nigeria. An Unpublished M. Sc Dissertation Submitted to the Department of Geology, Ahmadu Bello University Zaria, Nigeria.

Hayes, K., (2008). Artisanal \& Small-scale Mining \& Livelihoods in Africa. Paper prepared for an international seminar titled: "Small-scale Mining in Africa - A Case for Sustainable Livelihood" Prior to the opening of the 20th Annual Meeting of the Governing Council of the Common Fund for Commodities 25-26 November, at the Zanzibar Beach Resort, Zanzibar, Tanzania.

Kebbi State Government, (2003). Kebbi State Government Official Diary. Directorate of Information, Kebbi, Nigeria.

Lawal, M., (2002). Constraints To Small Scale Mining In Nigeria: Policies and Strategies for Development, CEPMLP Research publications, pp. 6 .

Michelou, J.C., (2006). Baseline Study of the Nigerian Gemstone Industry Development. A report prepared for the Ministry of Solid Minerals Development, Federal Republic of Nigeria.

Ministry of Mines and Steel Development (MMSD), (2008). National Baseline Study on the Development of Artisanal Small Scale Mining in Nigeria. Draft report presented to the Ministry of Mines and Steel Development of the Federal Government of Nigeria by Kevin D’ Sousa.

Mondlane, S., and Shoko, D.S.M., (2003). The socio-economic and environmental impacts of artisanal and small-scale mining in Mozambique. In: G. M. Hilson (Ed.), the socio-economic impacts of artisanal and small-scale mining in developing countries, Netherlands. pp. 265-280.

Oladeji J.O., Thomas, K. A. and Ige, S.O.O. (2010). Impacts of Mining on Income Generating Activities of Rural Dwellers in Itesiwaju Local Government Area of Oyo State, Nigeria. International Journal of Applied Environmental Sciences. Vol. 5(6):889-897.

Olayide P.B., Olawoye, J.E. \& Olayide, O.E. (2011). Gender Dimensions of Rural Livelihoods in Artisanal and Small-scale Mining in Itesiwaju Local Government Area of Oyo State, Nigeria Centre for Sustainable Development, University of Ibadan, Nigeria.

Salati L.k., Mireku-Gyimah D., and Eshun P.A., (2014). Evaluation of Stakeholders' Roles in the Management of Artisanal and Small-Scale Gold Mining in Anka, Zamfara State, Nigeria.

www.scirj.org

(C) 2020, Scientific Research Journal

http://dx.doi.org/10.31364/SCIRJ/v8.i4.2020.P0420769

This publication is licensed under Creative Commons Attribution CC BY. 
Sani G.D., Danladi B.S., Lawali S., Amina M.B (2019) Identification of Mineral Deposits in Garin Awwal Mining Site. Journal of Multidisciplinary Engineering Science and Technology. Vol.6 Issue 6, pp. 10276-10280.

Talaat M., and Mohammed, F. Abdel Fattah (2010). The Egyptian journal of remote sensing and space science. Vol. 13, issue 2. Pp. 153-163.

Udu R.K., (1991). Geographical regions of Nigeria, Longman Ltd. pp. 21-27

Zankan, J. A. A. (2018). Assessment of Commercial Woodfuel Harvesting and its Environmental Implications in Jema'a Local Government, Kaduna State, Nigeria. An Unpublished M. Sc Dissertation Submitted to the Department of Geography Bayero University, Kano

\section{Personal Communications}

Audu, U. (2017) Tondi Gada, Blacksmith, personal communication, December 05, 2017

Hassan, G. (2017) Garin Hawal, Miner, personal communication, November 01, 2017

Isah, R. (2017) Tondi Gada, Miner, personal communication, December 05, 2017

Jatau S. (2017) Garin Hawal, Miner, personal communication, November, 01, 2017

Kulu, T. (2017) Tondi Gada, food Vendor, personal communication, December 05, 2017

Mamman Z. (2017) Garin Hawal, Hunter, personal communication, November, 01, 2017

Nuhu, F. (2017) Garin Hawal, Miner, personal communication, November 01, 2017

Tanko, Y. (2017) Tondi Gada, Miner, personal communication, December, 05, 2017

www.scirj.org

(C) 2020, Scientific Research Journal

http://dx.doi.org/10.31364/SCIRJ/v8.i4.2020.P0420769

This publication is licensed under Creative Commons Attribution CC BY. 